\title{
10 Years of the Polish Communication Association
}

Bogusława Dobek-Ostrowska

UNIVERSITY OF WROCEAW

Michał Głowacki

UNIVERSITY OF WARSAW

EDITORS OF THE CENTRAL EUROPEAN JOURNAL OF COMMUNICATION

DOI: 10.19195/1899-5101.10.1(18).1

April 22, 2017 marks the 10th anniversary of the creation of the Polish Communication Association (PCA) - an organization that gathers media and communication scholars from Poland and beyond. We met each other in Wrocław back in 2007 for a conference which aimed to establish a professional organization that could support the development of media and communication studies in Poland and further serve as a platform for knowledge exchange between scholars and media professionals internationally. Over the last 10 years the Polish Communication Association has undertaken a wide range of activities to integrate scholars' communities and to make the work of Polish academics more visible in Europe and beyond. Today, with more than 250 active members it continues to grow with aspirations of being the most dynamic professional association in social science in Poland.

The Polish Communication Association community has done a lot to fulfill goals defined in its statute with the most significant success in 2011, where the Ministry of Science and Higher Education established media studies as an autonomous scientific discipline in Poland. Scholars representing a variety of methodological and theoretical approaches have been active in the work of the research sections, which underline an interdisciplinary character in communications and media. The Association has systematically monitored publications of its members and further supported their efforts in publication and conference activities by providing both financial support and patronage. For us one of the most important things has also been to support young scholars, for whom the award for best $\mathrm{PhD}$ dissertation has created opportunities to be more recognized in academic work. Our goal has also been to reward scholars who have made a significant contribution to the development of communication and media studies. 


\section{AUTHORITIES OF THE PCA}

Four Executive Committees were elected during the last 10 years of PCA's activity: 2007-2010 Bogusława Dobek-Ostrowska (President), Piotr Francuz (VicePresident), Iwona Hofman, Zbigniew Oniszczuk, Katarzyna Pokorna-Ignatowicz, Kazimierz Wolny-Zmorzyński, Michał Kuś (Secretary),

2010-2013 Bogusława Dobek-Ostrowska (President), Iwona Hofman (VicePresident), Michał Drożdż, Małgorzata Lisowska-Magdziarz, Jerzy Olędzki, Zbigniew Oniszczuk, Agnieszka Stępińska, Paweł Baranowski (Secretary),

2013-2016 Iwona Hofman (President), Zbigniew Oniszczuk (Vice-President), Bogusława Dobek-Ostrowska, Michał Drożdż, Alicja Jaskiernia, Małgorzata Lisowska-Magdziarz, Dorota Piontek, Agnieszka Stępińska, Małgorzata Adamik-Szysiak (Secretary),

2016-2019 Iwona Hofman (President), Zbigniew Oniszczuk (Vice-President), Bogusława Dobek-Ostrowska, Michał Drożdż, Alicja Jaskiernia, Małgorzata Molęda-Zdziech, Dorota Piontek, Małgorzata AdamikSzysiak (Secretary).

\section{CONGRESSES OF THE PCA}

The congresses of the Polish Communication Association are among the most important events that gathered the biggest number of participants.

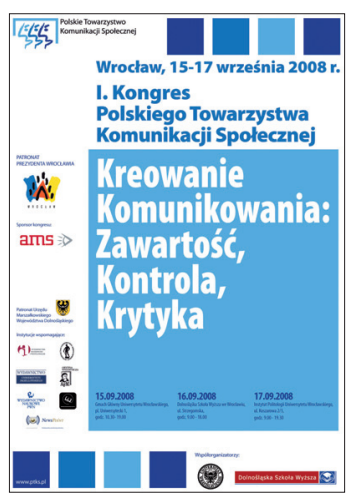

2008 The 1st Congress in Wrocław Creation of communication, content, control, critics was organized at Aula Leopoldinum in the historical building of the University of Wrocław. Many prominent foreign and Polish scholars accepted an invitation to take part in this event - Prof. Wolfgang Donsbach (Germany), Prof. Paolo Mancini (Italy), Prof. Graham Murdock (United Kingdom), Prof. Winfried Schulz (Germany), Prof. Donald Shaw (USA), Prof. Gerald Sussman (USA). Among the guests were also Polish scholars - Prof. Walery Pisarek, Prof. Tomas Goban-Klas, Prof. Mirosław Karwat, and Prof. Jerzy Mikułowski Pomorski.

During the Congress Honorary Membership to excellent scholars was awarded to 'Fathers' of communication science in Poland - Prof. Walery Pisarek and Prof. Jerzy Mikułowski Pomorski. PCA Honorary Membership was also granted to a great friend and supporter of Polish scholars - Prof. Wolfgang Donsbach (Germany). 


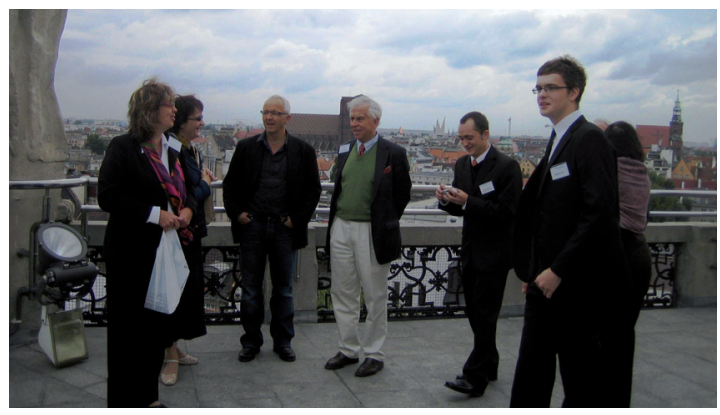

The guests on the University tower

Source: Archive of PCA

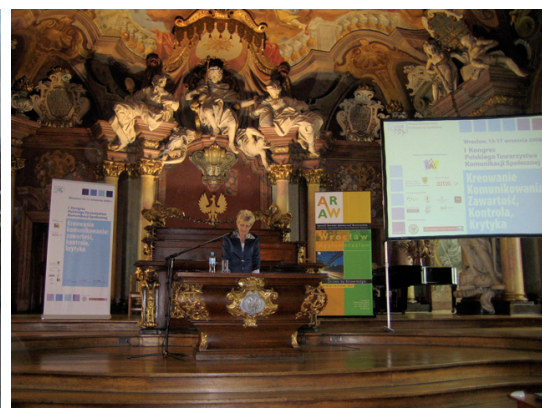

Opening ceremony

Source: Archive of PCA

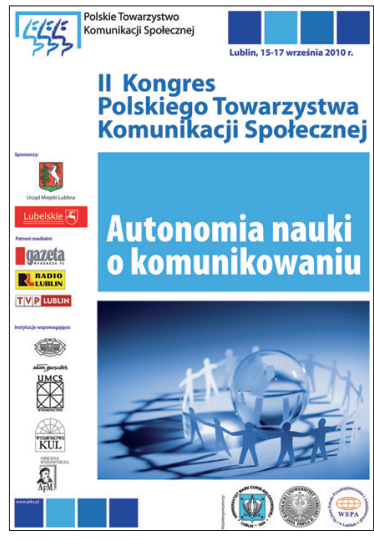

2010 The 2nd Congress in Lublin Autonomy of communication sciences was organized at the Polish Painting Gallery in Lublin Castle. Many very well-recognized scientists from different countries arrived in Lublin; Prof. David Weaver (USA) and Prof. Wayne Wanta (USA), Prof. Allan Stuart (United Kingdom), Prof. Auke Balčytienè (Lithuania), Prof. Inta Brikše (Latvia), Prof. Susanne Fengler (Germany), Prof. Epp Lauk (Estonia), Prof. Stephan RussMohl (Switzerland), and Prof. Jesper Strömbäck (Sweden) were among the main guests of the conference.

Honorary Membership of the PCA was awarded to Prof. Wayne Wanta from the USA, who co-works with Polish scholars and supports them, and Prof. Tomasz Goban-Klas, one of the best specialists in communication sciences in Poland.

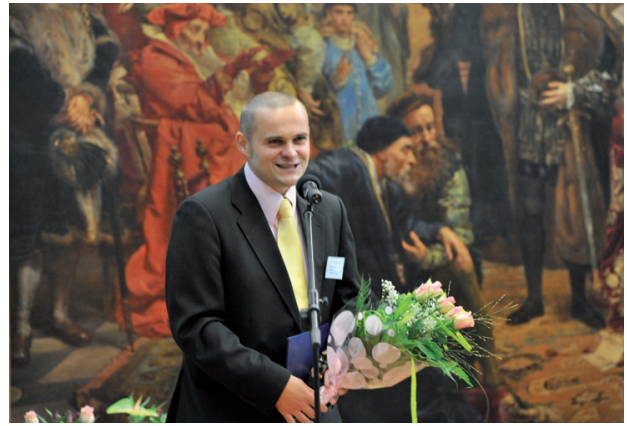

The Opening Ceremony, Dr Sławomir Czapnik - laureate of the Ph.D. Prize

Source: Archive of PCA

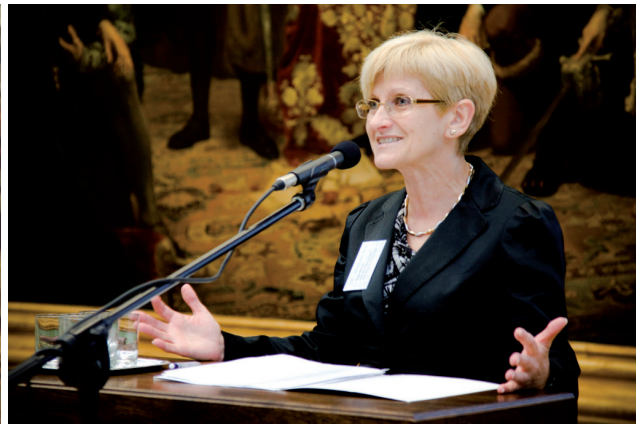

The speech of President of PCA - Bogusława Dobek-Ostrowska

Source: Archive of PCA 


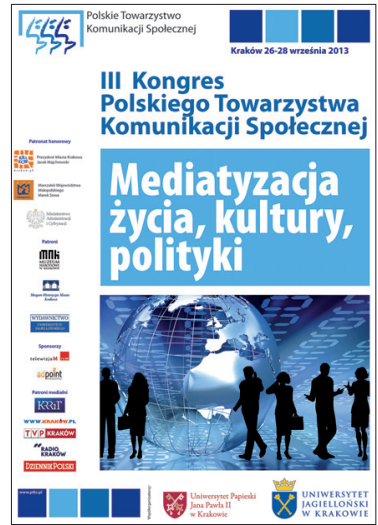

2013 The 3rd Congress in Cracow Mediatization of life, culture and politics took place in the Palace of Larisch (18th Century). Keynote speeches were delivered by Prof. Paolo Mancini (Italy), Prof. Andreas Hepp (Germany), and Prof. Ramon Salaverria (Spain).

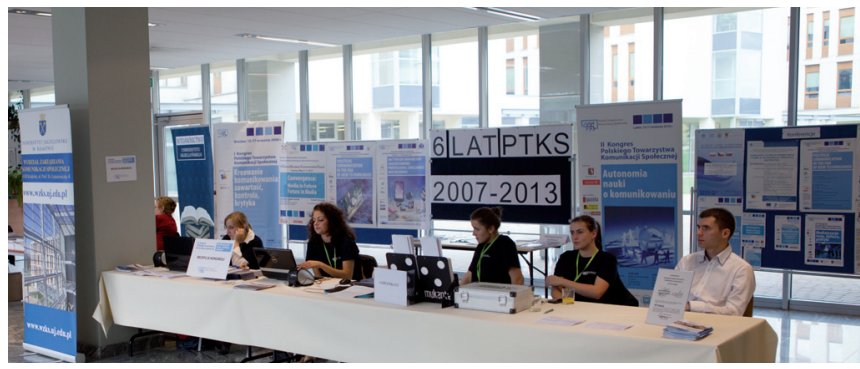

The 3rd Congress was a good occasion to present 6 years of PCA activity and to promote the Central European Journal of Communication -4 years after publication of the first volume

Source: Archive of PCA.

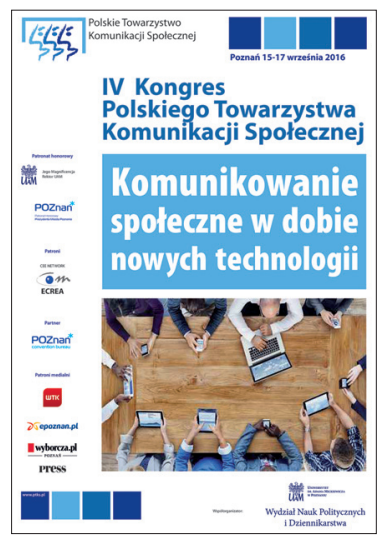

2016 The 4th Congress in Poznan Social communication in the time of new technologies confirmed that the milieu of media and communication scholars is consolidated. Prof. Barbara Pfetsch (Germany), Prof. Richard Hornik (USA), Dr. Vaclav Štetka (Czech Republic), and Prof. Bogusława Dobek-Ostrowska (Poland) were among the keynote speakers. Honorary Membership of PCA was awarded to Prof. Jerzy Olędzki.

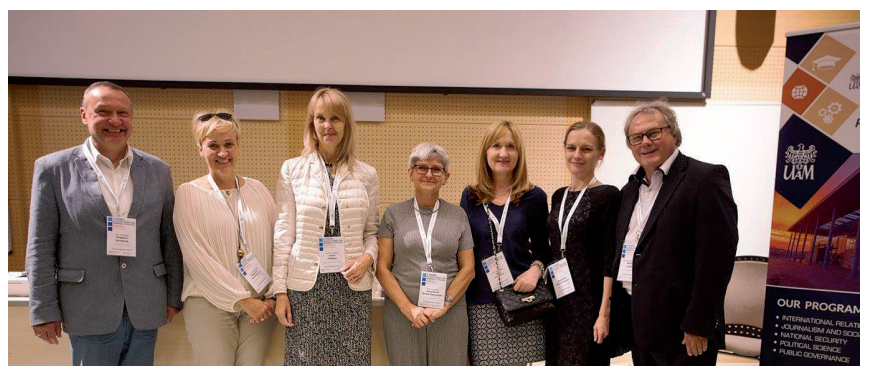

The newly elected Executive Committee for 2016-2019

Photo: Dominik Kłos. 


\section{INTERNATIONAL CONFERENCES}

The Polish Communication Association has also organized several international conferences in Poland. The list of events organized and/or co-organized by the PCA include:

2008 Castle Książ 1st Polish-Czech-Slovak Forum of Political and Communication Sciences - the first meeting of scholars from Poland, the Czech Republic and Slovakia, which - in fact - opened a tradition of organizing annual CEECOM conferences in Central and Eastern Europe.

2011 Cracow 4th Central European Communication Forum Convergence: Media in Future, Future in Media.

2011 Warsaw International Conference Political Communication in the Era of New Technologies, co-organized by the University of Warsaw.

2012 Gdańsk International Conference Matters of Journalism: Understanding Professional Challenges and Dilemmas, co-organized by the University of Gdańsk.

2014 Wrockaw 7th International CEECOM Conference Changing Media and Democracy: 25 Years of Media Freedom and Public Sphere in Central and East Europe, co-organized by the University of Wrocław.

\section{CENTRAL EUROPEAN JOURNAL OF COMMUNICATION THE OFFICIAL JOURNAL OF THE POLISH COMMUNICATION ASSOCIATION}

One of the main activities has always been to support the publication of the Central European Journal of Communication. Acting as a forum for empirical, critical and interpretative, quantitative and qualitative studies we did our best to promote research conducted in Central and Eastern Europe and to further build research platforms for researchers representing different parts of the world. There have been 17 volumes published in the period of Fall 2008-Fall 2016; 209 authors from 5 continents and 31 countries published 145 articles in total. Readers may find 8 interviews with prominent scholars and 48 reviews of the most important books in communication and media studies. The Journal is abstracted and indexed in the following scientific databases: Thomson Reuters Emerging Sources Citation Index (ESCI), SCOPUS, ERIH Plus, List of scientific journals of Ministry of Science and Higher Education in Poland 2016, IC Journals Master List 2015, The Central and Eastern European Online Library (CEEOL), The Central European Journal of Social Sciences and Humanities (CEJSH), Bazhum and Google Scholar Metrics.

\section{Honorary Membership of the PCA}

PCA Honorary Membership is awarded to prominent scholars; the ceremony is organized during the most important PCA events. 

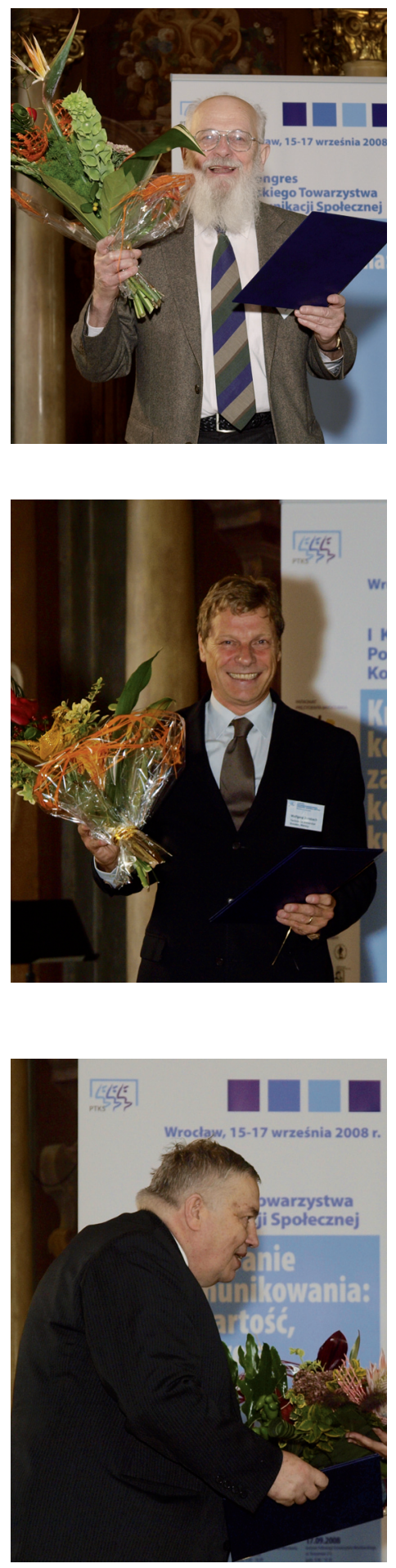

Prof. dr hab. Walery Pisarek was awarded Honorary Membership during the 1st Congress of PCA in 2008 in Wrocław. He is one of the first scholars interested in research on media and communication in Poland. He is the author of numerous publications emphasizing the history of the Polish language, journalism theory and mass communication. He worked at the Jagiellonian University in Cracow. In the period 1969-2000 he served as director of the Centre for Research on the Press in Cracow. He was the first President of the Polish Language Council.

Prof. Ph.D. Wolfgang Donsbach (1949-2015) was awarded Honorary Membership during the 1st Congress of the PCA in 2008 in Wrockaw. He was a professor of communication at the Department of Communication at Dresden University of Technology, Germany, of which he was also the founding director. He received his $\mathrm{PhD}$ and his postdoctoral dissertation at the University of Mainz. He taught at the universities in Dortmund, Mainz, and Berlin. From 1995 to 1996 he was President of the World Association for Public Opinion Research (WAPOR) and from 2004 to 2005 President of the International Communication Association (ICA).

Prof. dr hab. Jerzy Mikułowski Pomorski was awarded Honorary Membership during the 1st Congress of the PCA in 2008 in Wrocław. He is a sociologist and media expert in the field of sociology of culture, international relations and intercultural communication. In the 1970s he was head of the Division of International Economic Organizations at the Economic University in Cracow. He then held the position of deputy director of the Institute for International Socio-Economic Affairs, Head of the Department of European Studies as the Rector of the Economic University in Cracow. He also worked at the Silesian University in Katowice as well as at the School of Social Sciences. 

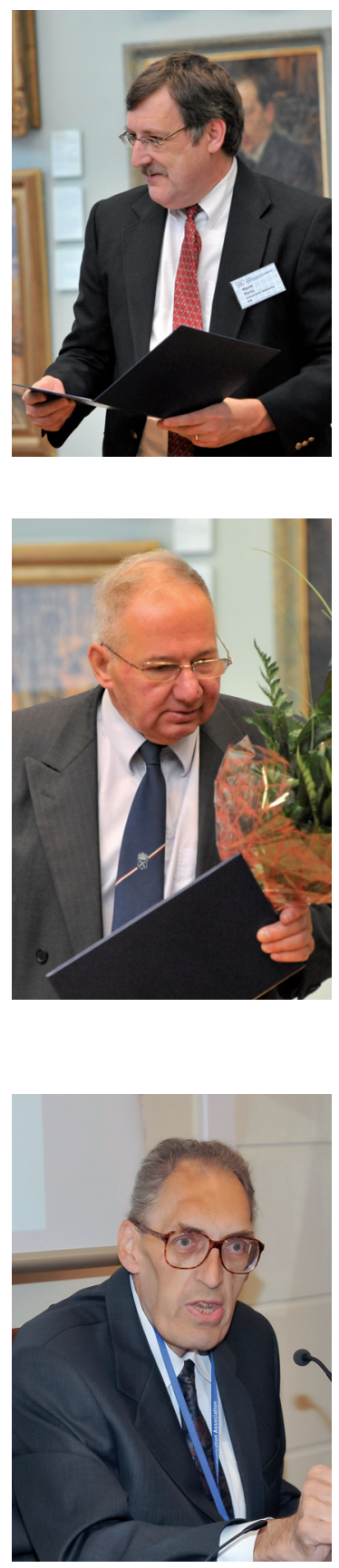

Prof. Ph.D. Wayne Wanta was awarded Honorary Membership during the 2nd Congress of the PCA in 2010 in Lublin. He holds the Welch-Bridgewater chair in the School of Journalism and Broadcasting at Oklahoma State University (USA). He has authored and co-authored four books and more than 150 refereed journal articles and convention papers, many dealing with the agenda-setting function of the news media. He is also the past president of the Association for Education in Journalism and Mass Communication. He is a professor at the College of Journalism and Communication at the University of Florida.

Prof. dr hab. Tomasz Goban-Klas was awarded Honorary Membership during the 2nd Congress of the PCA in 2010 in Lublin. He is a professor of media, a specialist in the field of public opinion research, communication, sociology of culture as well as mass communication theory. He graduated from the Jagiellonian University. He worked at the Institute of Philosophy and Sociology at the Polish Academy of Sciences and further served as scientific secretary of the Centre for the Research on the Press, in Cracow. In the early 1990s he was a professor at the Institute of European Studies in Vienna. In the years 1992-1996 he was vice-president of the Journalists' Association of the Republic of Poland (SDRP).

Dr Karol Jakubowicz (1941-2013) was awarded Honorary Membership in 2011 during the international conference of the PCA in Warsaw. He was a media expert on broadcasting media at the Council of Europe, the European Union, the European Broadcasting Union, and the Organization for Security and Co-operation in Europe. He was Chairman of the Intergovernmental Council of the UNESCOInformation for All Programme and a member of the Independent Media Commission in Kosovo. In 2005-2006 he was Chairman of the Steering Committee on the Media and New Communication Services at the Council of Europe. He worked in academia, in the media industry, and in the National Broadcasting Council of Poland. His publications on media and communication studies were published in Poland and internationally. 

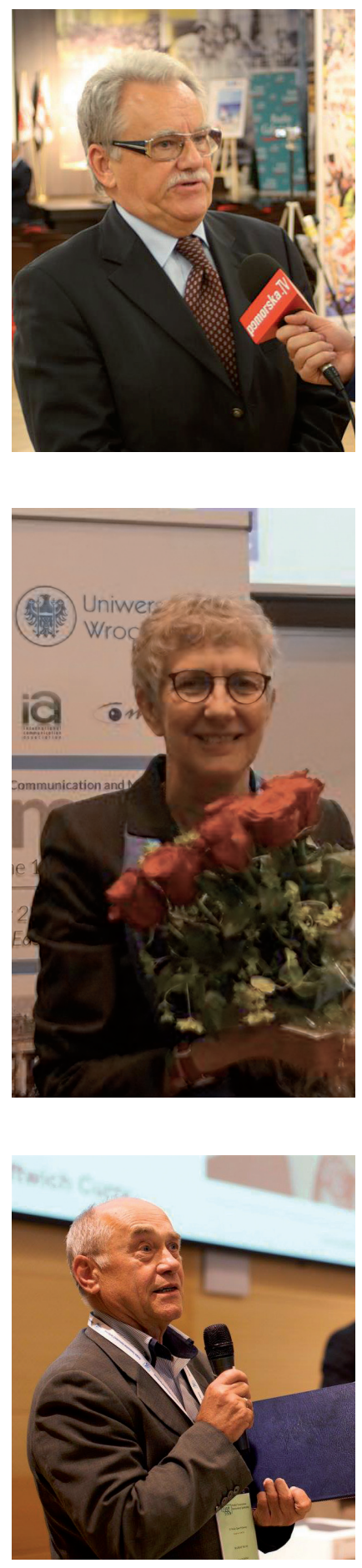

Prof. dr hab. Wiktor Pepliński was awarded Honorary Membership in 2012 during the international conference of the PCA in Gdańsk. He is professor of media studies. He is interested in history of media and changes since 1989 in Poland. He is the author of many books and articles, some of which are dedicated to the press in the northern Polish region of Kaszuby. He has been a member of many expert teams working on the standards of journalistic studies in Poland and Polish Accreditation Commission. He is a member of the editorial board of several communication and media academic journals in Poland.

Prof. Ph.D. Jane Leftwich Curry was awarded Honorary Membership in 2014 during the 7th International CEECOM Conference in Wrocław. She is a professor of political science at Santa Clara University in California, USA. She visited Poland for the first time in the 1960s. After that she often returned there. She has published a lot of books, seven monographs and about 40 articles and chapters. Many of them are dedicated to Poland. The list of publications includes Central and East European Politics: From Communism to Democracy (2007), Poland's Journalists: Professionalism and Politics (1990) and The Black Book of Polish Censorship (1984), they are important and fundamental for understanding the process which took place in communist regimes in Central and Eastern Europe and in the post-communist period.

Prof. dr hab. Jerzy Olędzki was awarded Honorary Membership in 2016 during the 4th Congress of the PCA in Poznan. He was a co-founder of the PCA and a member of the PCA Executive Committee in the period 2010-2013. He worked for the University of Warsaw, and he continues his academic career at the University of Stefan Wyszyński. He was a visiting professor at Ohio University (USA). He is the author of publications related to public relations. He is a member of many editorial boards of academic journals. 


\section{Membership of the PCA in the International Communication Association}

The Polish Communication Association is a collective member of the ICA. This type of membership helps to organize a panel (sponsored session) during the annual conferences of the ICA. These sessions are among the most important tools for the PCA's promotion. Thanks to this activity, Polish scholars can distribute their knowledge to a wider international public. The list of PCA panels during the annual ICA conferences includes:

2009, Chicago (USA), 59th Annual ICA Conference Keywords in Communication. Panel of the PCA: "25 Years of Free Media and Public Sphere in Central Europe" (Participants: Bogusława Dobek-Ostrowska, Robert Wiszniowski, Auksė Balčytienė, Jaromír Volek, Michał Głowacki, Andrej Skolkay, Respondent: Paolo Mancini),

2010, Singapore (Singapore), 60th Annual ICA Conference Matters of Communication. Panel of the PCA: "Polish Electoral Campaigns and Political Communication in Comparative Perspective" (Participants: Bogusława Dobek-Ostrowska, Marek Mazur, Marek Piasecki, Bartłomiej Biskup, Dorota Piontek, Robert Szwed, Respondent: Wolfgang Donsbach),

2011, Boston (USA), 61st Annual ICA Conference Back to Planet Earth (or Society). Panel of the PCA "Public Relations and Social Media" (Participants: Jerzy Olędzki, James E. Grunig, Jacek Barlik, Astrid Spatzier, Benno Signitzer, Maria Jose Canel, Respondent: Jane Leftwich Curry),

2012, Phoenix (USA), 62nd Annual ICA Conference Communication and Community. Panel of the PCA: "Journalistic Professionalism Around the Baltic" (Participants: Bogusława Dobek-Ostrowska, Joran Hok, Gunnar Nygren, Agnieszka Stępińska, Michał Głowacki, Auksè Balčytienė, Elena Dagtereva, Maria Anikina, Respondent: Owen Johnson and Peter Gross),

2013, London (United Kingdom), 63rd Annual ICA Conference Challenging Communication Research. Panel of the PCA: "Media Accountability in the Digital Age: An International Perspective" (Participants: Bogusława Dobek-Ostrowska, Susanne Fengler, Stephan Russ-Mohl, Tobias Eberwein, Cristina Coman, Racula Radu, Michal Kuś, Olivier Baisnee, Sandra Zambrano, Judith Pies, Respondents: Kaarle Nordenstreng, Davied Weaver, Scott Maier),

2014, Seattle (USA), 64th Annual ICA Conference Communication and The Good Life. Panel of the PCA: "25 Years of Media Freedom and Democracy in Central and Eastern Europe" (Participants: Iwona Hofman, Michał Głowacki, Alina Dobreva, Zrinjka Peruško, Respondents: Jane Curry and Elza Ibroscheva),

2015, San Juan (Puerto Rico), 65th Annual ICA Conference Communication Across the Life Span. Panel of the PCA: "Journalism Education in the Digital Mediascapes" (Participants: Iwona Hofman, Wolfgang Donsbach, Peter Gross, Gunnar Nygren, Michał Głowacki, Respondent: Barbie Zelizer), 
2016, Fukuoka (Japan), 66th Annual ICA Conference Communication through Power. Panel of the PCA: "Public Service Media: An Idea of the Enlightenment?" (Participants: Iwona Hofman, Tim Raats and Karen Donders, Manuel Puppis, Laia Castro Herrero, Corinne Schweizer, Peter Gross, Nick Gross, Lizzie Jackson, Michał Głowacki).

\section{INTERNATIONAL ACTIVITY OF THE PCA CENTRAL AND EASTERN EUROPEAN COMMUNICATION AND MEDIA (CEECOM) CONFERENCES}

The PCA co-works with the International Association for Media and Communication Research (IAMCAR), European Communication Research and Education Association ECREA) and the International Political Science Association (IPSA). Through the platform of the Central and Eastern European Communication and Media (CEECOM) consortium, the PCA has supported the organization of the annual CEECOM conferences. It started in Poland, and in subsequent years CEECOM conferences were organized in other Central and Eastern European countries: 2008 Castle Książ (Poland), 1st Polish-Czech-Slovak Forum of Political and Communication Sciences,

2009 Brno-Telc (Czech Republic), 2nd Czech-Polish-Slovak Communication Conference Channels of Transition,

2010 Bratislava (Slovakia), 3rd Slovak-Czech-Polish-Hungarian-Austrian Forum Media in Crisis. Crisis in Media,

2011 Cracow (Poland), 4th Central European Communication Forum Convergence: Media in Future, Future in Media,

2012 Prague (Czech Republic), Central \& Eastern European Communication and Media Conference Media Power and Empowerment,

2013 Kaunas (Lithuania), 6th International CEECOM Conference Liquidity, Fragmentation, and Individualization in the Mediascape,

2014 Wrocław (Poland), 7th International CEECOM Conference Changing Media and Democracy: 25 Years of Media Freedom and Public Sphere in Central and East Europe,

2015 Zagreb (Croatia), 8th International CEECOM Conference The Digital Media Challenge,

2016 Tartu (Estonia), 9th International CEECOM Conference Media and Communication Studies: Bridging, Disciplines, Bridging Countries.

We use the opportunity of publishing this Spring 2017 issue to congratulate the PCA and to thank all the members of the Polish Communication Association community for their support and engagement.

We wish all of you who come to celebrate the 10th PCA anniversary in Wrocław fruitful discussions on all the previous achievements as well as communication and media studies going forward. 